\title{
A reflective analysis of articles published in the journal of Transformation in Higher Education (2016-2020): Beyond transformation?
}

Author:
Anne Becker ${ }^{1}$
Affiliation:
'Department of Curriculum
Studies, Faculty of
Educational Sciences,
Stellenbosch University, Cape
Town, South Africa
Corresponding author:
Anne Becker,
annebecker@sun.ac.za
Dates:
Received: 30 Sept. 2020
Accepted: 14 Oct. 2020
Published: 04 Dec. 2020
How to cite this article:
Becker, A., 2020, 'A reflective
analysis of articles published
in the journal of
Transformation in Higher
Education (2016-2020):
Beyond transformation?',
Transformation in Higher
Education 5 (0), a98. https://
mobile device
doi.org/10.4102/the.v5i0.98
Copyright:
Co 2020. The Author.
Licensee: AOSIS. This work
is licensed under the
Creative Commons
Attribution License.

Background: The fault lines exposed by the Coronavirus disease (COVID-19) pandemic and global economic recession unfolding during 2020 in societies around the world, reiterated the need for transforming higher education globally. In South Africa, transformation in higher education has been a priority since 1994. The first article in this journal was published in 2016 during the 2015-2016 \#mustfall protests. During the protests, decolonisation and decolonising of higher education were central.

Aim: A reflective analysis of articles published in the journal of Transformation in Higher Education 2016-2020.

Setting: Transformation and decolonising in global and South African higher education.

Method: A reflective analysis is done through a decolonial lens. The contributions of authors are reflected upon through three themes: place (local and global), epistemology and alienation.

Results: Although I find the engagement with decolonising substantive, I argue that there is still a lack of publications on specifically decoloniality and decolonial analysis.

Conclusion: I argue that the journal of Transformation in Higher Education provides a platform for difficult and robust discussions on decoloniality, transformation, epistemology, issues of sexuality, gender and race, internationalisation and possible pluriversalisation in higher education for South African and international scholars.

Keywords: alienation; epistemology; decoloniality; local and global; pluriversality; transformation.

\section{Introduction}

This article is a reflective analysis of articles published in the journal of Transformation in Higher Education (THE) (2016-2020). It is a reflection on how transformation in higher education is enunciated by authors publishing in this journal. The Coronavirus disease (COVID-19) pandemic and global economic recession unfolding during 2020, situate this reflection in time-place-space. Although the pandemic has impacted everyone, it has put the spotlight on the consequences of global economic and political power, capitalism and neo-liberalism (Peters et al. 2020). These consequences have been particularly stark in South Africa.

A central theme of the pandemic is the universal right to breathe (Mbembe 2020). Many people around the world would, however, argue that the earth, cosmos and the majority of humankind have already been in a premature cessation of breathing before the pandemic (Mbembe 2020). The globally suffocating consequences of growing inequality and desperate poverty and suffering, continually masked by narratives of global economic development and progress, became clearly visible to everyone during 2020. The events of 2020 put, otherwise invisible, disposable bodies in societies on public display, through social media, print media and global digital communications. The consequences on display are not only related to class and inequality but also race and gender (femicide in South Africa specifically). The 2020 global Black Lives Matter protests, for example, attest to the suffocating consequences of global racism. Race, as an organising principle, is a central axis of colonialism and coloniality, and Maldonado-Torres (2007:243) argues that 'as modern subjects, we breathe coloniality all the time and every day'. It defines human relations, subjectivities, identities, cultures and knowledge (Maldonado-Torres 2007:243).

Catastrophic events, such as pandemics, always involve disruption (Quay in Peters et al. 2020:10). The pandemic and its consequences brought about cognitive, emotional, physical, spatial, social, 
educational, political and economic disruption. It required populations all over the world to continually change their lives in the midst of ongoing uncertainty (Peters et al. 2020:10).

Certainty in education is recorded via facts and catalogued in curricula (Quay in Peters et al. 2020:10). The facts recorded in curricula were not disrupted during the pandemic. Facts were, through disrupted education practices and processes, positioned differently. The practices of education and how we teach and learn were disrupted and are now steeped in uncertainty (Quay in Peters et al. 2020). This had consequences, as Quay (in Peters et al. 2020:11) poses: 'The pedagogical changes wrought via the pandemic have positioned facts differently; their certainty is clothed in various forms of practice which alter their meaning: how they are known'.

Digital technologies, already in use before the pandemic, became the core means of teaching and learning. Traditional education was replaced by online teaching across the world, and there can be no doubt that online education works differently from face-to-face teaching and learning (Jackson in Peters et al. 2020:23). Online teaching has many positive possibilities. It is argued that access to quality education is increased and with it a global sense of citizenship and sociality. There are, therefore, many calls on educational administrators not to go back to traditional ways of teaching and learning. (Jackson in Peters et al. 2020:24).

Digital technologies, however, also carry risks. Whilst online teaching and learning are presented as a way of expanding access to education, the current (forced) experiment highlighted global dimensions of unequal access, inadequate or non-existent internet access, lower quality equipment and limited experience with platforms such as Zoom or Skype. Fataar (in Peters et al. 2020:27) poses that the pandemic 'simultaneously engages, intensifies and subverts existing educational inequity and iniquity'. Globally the gains of expanding access could be wiped out by the loss of opportunities for some. In South Africa, only $20 \%$ of the country's educational institutions managed to move to efficient online teaching and learning (Fataar in Peters et al. 2020). Access to efficient online teaching and learning in South Africa remains along the lines of colonial and apartheid privileges. For the majority of the country's students, the pandemic lockdown meant no education (Fataar in Peters et al. 2020).

Papastephanou (in Peters et al. 2020:16) postulates that universities (in Greek panepistimia - all sciences) and pandemics (all people) share the prefix 'pan-', which means 'all'. The universality of all sciences and all people (panepistimia and pandemic) points to an interconnectedness of people and knowledge, which needs to be reimagined at this time of crisis. During such a reimagination, a new reality can emerge when 'aspirational thought becomes pandemic' (Papastephanou in Peters et al. 2020:16). How then can such reimaginations become 'pandemic' when thinking transformation in higher education?
After more than a decade of writing, talking and debating transformation in South African higher education, the \#mustfall protests (2015-2016) in South Africa laid bare the little progress made. The pandemic reiterated the lack of transformation in higher education. This is, therefore, a time for change, for thinking differently of transformation, for thinking differently about new beginnings. It is time to think critically and honestly about what we envision for higher education in South Africa.

In the first article published in the journal of THE, the editors explained their view on transformation as follows: 'the concept 'transform' is therefore not the result of external forces but is, in fact, programmed by the concept (transform) itself. In other words, the fuzziness of 'transform' reflects the inherent complexity of the concept' (Du Preez, Simmonds \& Verhoef 2016:1). They argue for an open-ended rethinking of the concept transformation. Davids (2016:5), similarly, poses that transformation both 'reveals and conceals that which is not immediately visible'. It is Waghid (2016:4) who states that if higher education needs to become transformative whilst remaining in potentiality 'it has to be thought of differently'. Both transformation and higher education, as well as transformation in higher education, need to be thought of differently.

In reading through the titles, abstracts and keywords of the published articles since 2016, it seems that many authors (13 out of 35) advocate for decolonisation and decolonising as crucial to transformation. Decolonisation and decolonising became key to, or even equal to, transformation in higher education during and after the \#mustfall protests in 20152016. Decolonisation and decolonising are explicit or implicit in titles, abstracts and keywords related to notions such as epistemic violence and Eurocentric hegemony (Heleta 2016), Africanisation (Horsthemke 2017), colonial and decolonial identity and subjectivity (Bazana \& Mogatsi 2017; Becker 2017; Mabille 2019), black consciousness and black studies (Bazana \& Mogatsi 2017; Lamola 2018), indigenisation and indigenous knowledge (Eybers 2019; Horsthemke 2017), decolonial curriculum (Nyoni 2019), postcolonialism (Gearon 2019; Nell 2020) and decolonial philosophy (Matolino 2020).

This reflection is done through a decolonial lens. The decolonial turn in humanities, whilst acknowledging the many contributions of postcolonial scholars, shifted decolonisation work towards an expanded and more indepth analysis of colonialism and coloniality and its production of the other (García \& Baca 2019:2). Scholars such as Mignolo (2018a), Maldonado-Torres (2016) and NdlovuGatsheni (2019) highlight how postcolonialism has European history and knowledge as a point of reference for understanding the global world. Decolonial scholars, therefore, critique the post in postcolonial studies by claiming that coloniality still dominates the world today (García \& Baca 2019). Decoloniality is thus different from postcolonialism, anti-colonialism and related decolonisation movements. Decoloniality is specifically formalised by the colonised in the Global South to dismantle global relations of 
power and conceptions of knowledge reproducing racial, gender and geo-political hierarchies (Ndlovu-Gatsheni 2019).

The ongoing consequences of global economic power, political power and the reproduction of hierarchies made visible during 2020 make the interconnectedness implied in both panepistimia and pandemic difficult to reimagine, and a decolonial lens is therefore proposed.

\section{A decolonial lens}

Maybe in the time of a pandemic and economic recession and immense suffering, it is time for higher education to 'go back to school' in order to search for different knowledge and different ways to teach and learn (Biesta in Peters et al. 2020:31). The origin of the word school goes back to the Greek word for 'leisure'. Not a time to relax, but a time-emancipated from economic activities - to contemplate and to think. It also refers to showing, representing and teaching (Biesta in Peters et al. 2020:30) - teaching about the world and the people in the world. It is not about control, management, efficiency, economics or numbers. Biesta (in Peters et al. 2020:31) argues that this crisis demands from higher education to go back to contemplation and thinking and to 'come to judgment, rather than rely[ing] on our quick reflexes'.

In reimagining the interconnectedness of all sciences and all people (panepistimia and pandemic) whilst not relying on quick reflexes, we might benefit from decolonial thinking and imagining. Walsh (2018) speaks of a decolonial beyond - a decolonial otherwise, which might be prudent during this time. For such an exploration, we need to go back to the beginning, the birth of coloniality and decoloniality - the beginning of colonialism.

Starting with Spanish and Portuguese colonisation in 1492, colonialism refers to the colonising of the physical spaces and bodies of the colonised by the coloniser (Suárez-Krabbe 2013). Decolonisation is understood as the undoing of colonialism or the process by which a colonised country gains independence (Mignolo 2018a). The success of the anti-colonial and decolonisation movements during and after the 1960s led to the liberation and independence of many colonies. However, the fact that the logic of coloniality was left intact points to the failure of these movements (Ndlovu-Gatsheni 2015). Colonialism and coloniality still constitutes the discursive landscape within which many forms of domination and exploitation are embedded (Ndlovu-Gatsheni 2019).

The logic of coloniality refers to colonial patterns and structures of power, knowledge and being, which Mignolo (2018a) explains as the colonial matrix of power. The colonial matrix of power is like the unconsciousness to Freud and the surplus value to Marx (Mignolo 2018a). The colonial matrix of power structures and controls global reality. It is a theoretical concept which, when analysed and unpacked, makes visible the suffocating consequences of ongoing colonial power, knowledge and being. It makes visible the invisible. The colonial matrix of power consists of two levels: the level of enunciation (terms) and the level of the enunciated (content). Enunciation (terms) structures and controls the enunciated (content). Knowledge, and specifically Eurocentric knowledge, as a remnant of colonialism and coloniality, is privileged in the matrix. It is embedded in the level of enunciation and the level of the enunciated (Mignolo 2018a). In the colonial matrix of power, epistemology (enunciation), specifically Eurocentric epistemology, structures and controls ontology (enunciated). Mignolo (2018a:135) poses that 'ontologies are cosmologic/epistemic creations' within the colonial matrix of power.

Both these levels (enunciation and enunciated) are connected by flow of energy in the spheres of knowledge, subjectivities and interests. Enunciation frames the enunciated and our praxis of living. This downward flow controls and secures management in the colonial matrix of power. Mignolo (2018a) illustrates this by referring to the 2008-2009 economic crisis and the quest to save capitalism. It was not a quest to save people from economic ruin but a quest to save the interests of capitalism. A similar situation is developing during this pandemic and the global economic recession. Whilst the initial concern was the many lives that might be lost because of the pandemic, it was soon replaced with an urgent quest to save capitalist interests from the pandemic.

The enunciation of who and what is human during modernity and colonialism was within a Euro-western framework and when many could not identify as such, a hierarchy amongst humans was established to rank and classify humanity. Racism and sexism were the consequences. Mignolo (2018a) states:

The question is not what is human and humanity but rather who defined themselves as humans in their praxis of living and applied their self-definition to distinguish and classify and rank lesser humans. (p. 153)

Understanding the colonial matrix of power is the first step in decolonising. As Mignolo (2018a:136) argues, 'you can hardly decolonise something about which you do not know how it works'. Decoloniality is an option for resisting and analysing modernity and colonialism and the colonial matrix of power. Decoloniality as an option is articulated 'in decolonial analytics of modernity and coloniality' (Mignolo 2018a:224). It is the 'core task' of decoloniality to analyse, unmask, make visible and problematise the colonial matrix of power (NdlovuGatsheni 2019:215). Decoloniality is also not a single event or act. It is an ongoing resistance to colonialism and coloniality.

I concede that decoloniality is not the only option for analysing modernity and coloniality. Mignolo (2018b) poses that modernity and humanism are under attack today from two perspectives: decoloniality and posthumanism. For him, however, posthumanism is a Eurocentric critique of the human, whilst decoloniality is a critique of both the Eurowestern conceptualisation of human and the posthuman. Zembylas (2018) contests this view and argues that both posthumanism and decoloniality share a strong critique of 
modernity and humanism, strongly advocate for social justice and share a distaste for dualisms and binary conceptualisations. Although posthumanism might be a strong contender to move transformation in higher education to an open-ended and different conceptualisation, posthumanism may not be adequate in making sense of the colonial condition and its consequences for South Africa.

Mignolo (2018b:170) poses that one of the main tasks of decoloniality and decolonising is 'to decolonise Man/Human, to liberate pluriversal humanity'. Liberating pluriversal humanity is anactofreimagining theimplied interconnectedness of panepistimia and pandemic - all knowledge for, and of, all people. A pluriversal humanity is structured and secured through pluriversal knowledge. Developing pluriversal knowledge systems is the aim of the decolonial intellectual project globally (Kumalo \& Praeg 2019). Although decolonial resistance is geared towards the possibility of a global pluriversal, it cannot be other than local. It is always embedded in specific and unique place-space-time. It is also always a contextual communal grassroots resistance towards reexistence and reclaiming of pluriversal knowledge and ways of being. This requires deep engagement with grassroots' struggles and movements (Kumalo \& Praeg 2019).

Control and management of, and in, the colonial matrix of power are downwards. Decolonial resistance is always upwards. In analysing and resisting the colonial matrix of power, the terms (enunciation) are unmasked, made visible and contested from the bottom up. This is done through multiple ways such as global and local movements, protests, grassroots projects and grassroots engagements. It is done by delinking from top-down hegemonic knowledges and relinking to bottom-up pluriversal knowledge (Mignolo 2018b). Maldonado-Torres (2016), for example, poses that student movements play a crucial role in resisting colonial higher education. In highlighting lived experiences of students on university campuses, he references a student poet Masisi (in Maldonado-Torres 2016), who during the protests in 2016 described the colonial/apartheid stripping of dignity and mental enslavement up to the point where 'I can no longer breathe' (Masisi in Maldonado-Torres 2016:6).

\section{Reflection}

The articles published in the journal of THE display a thorough engagement, through a variety of lenses, with transformation in higher education from both local and international authors and perspectives. Three themes crystallised: firstly, the notion of place and the relation between local and global; secondly, a robust exploration of epistemology, epistemological practices and curriculum; and lastly, the notion of alienation in terms of identity, subjectivity, gender, sexuality and technology. The power of colonial knowledge is central to all three themes.

\section{Place: Local and global}

The relation and movement between local and global are explored by many authors in the journal (Gearon 2019;
Horsthemke 2017; Lai 2018; Mariaye \& Samuels 2018; Nyoni 2019; Smith \& Vass 2017; Van de Laar, Rehm, \& Achrekar 2017). Gearon (2019) in his paper, entitled Securitisation theory and the securitised university: Europe and the nascent colonisation of global intellectual capital, argues that the growing trend of securitised universities in Europe is a very powerful political instrument. Analysing this phenomenon in reference to 'the what, the how, and the who for' of securitised knowledge, he argues, is paramount (Gearon 2019:9). He asks the following critical questions:

Are securitised universities a re-colonisation? If first-generation colonialism was premised on economic principles and masked by epistemological violence in the name of civilisation, is the securitisation of the university a re-colonisation, a new, a global colonisation, of epistemologies masked as the protection of freedoms and security from threat and fear? (p. 9)

Locally, Heleta (2016) argues that first-generation colonialism, premised on economic principles and epistemic violence, is still very much intact in South African higher education. Very little has changed since 1994 towards pluriversal knowledge systems in higher education, as there is not enough engagement with new knowledge-making ways. He states that although all universities have new policies and frameworks addressing freedom, equality, dignity and social justice, 'institutional cultures and epistemological traditions have not considerably changed' (Heleta 2016:2). The logic of Eurocentric coloniality stayed intact.

Contestations and resistance around notions of globalisation, Europeanisation and Africanisation in this journal and the broader academe remain embedded in the struggle to rid South Africa and Africa from colonial power embedded in hegemonic and universal Eurocentric knowledge and ways of being. Lamola (2018), in his critique of globalisation trends, poses that our thinking is:

Dazzled with imaginaries of 'global community', 'global village' and the concomitant ideal of cosmopolitanism. We are ethically impelled to aspire for the social ontology of a cosmopolitarian Being, the 'world citizen' who is not 'colour conscious'. (p. 3)

Horsthemke (2017) explains the essentialist nature of both Europeanisation and Africanisation. He argues that both fail to counter hegemonic universalism. He then argues for transcultural conversations on knowledge in higher education.

Arguments towards internationalisation in higher education are put forward in the journal. Smith and Vass (2017) argue that the internationalisation of universities and teaching could lead to transformation in changing assumptions and world views. Mariaye and Samuels (2018) explore internationalisation in educational hubs through econometrics, the travelling student, the customer student and parent, and marketisation. They warn that econometrics and marketisation are symptoms of the neo-liberal and capitalist saturation of global education. These symptoms are 
the masked enunciation of higher education as a capitalist project. Lai (2018) unpacks the Exchange Programme at the Hong Kong University and argues that the benefits are linked to cross-border, borderless, transnational and intercultural learning. The focus on intercultural (Lai 2018) and transcultural (Horsthemke 2017) learning might have possibilities for universalisation and global intellectual pluriversal projects.

Matolino (2020:7) returns to the local and argues towards a more embedded and embodied pluriversality. He argues for a deep engagement with 'the place'. Pluriversal projects need to engage Africa and South Africa with the respect they deserve. In the field of philosophy, for example, Africa and South Africa were for centuries excluded from conversations in and on philosophy apart from a single course in African philosophy at some universities. Africa and South Africa are part of, and embedded in, the pluriversal philosophical and epistemological experience in 'this place' (Matolino 2020:7).

\section{Epistemology and curricula}

Interrogating epistemology, epistemological practices and curricula are crucial to transformation in higher education. Authors in this journal have robust engagements with epistemology, epistemological practices and curriculum (Eybers 2019; Gearon 2017, 2019; Heleta 2016; Horsthemke 2017; Lomola 2018; Matolino 2020; Nyoni 2019; Ramrathan 2016; Simmonds \& Le Grange 2019; Venter 2016).

Ramrathan (2016) explains how transformation in higher education since 1994 has mostly taken on a number-counting, instrumentalised modality. The saturation of neo-liberalism and capitalism remains embedded in South African curricula practices.

Both Heleta (2016) and Nyoni (2019), after unmasking the coloniality of power and knowledge still intact in higher education, discuss approaches to transformation and decolonising in higher education. Heleta (2016) poses two approaches. The first is to add new knowledge to the existing curricula, and the second is to make visible the enunciation of knowledge and how it constructs curricula. The first approach is consistent with Eybers' (2019) notion of epistemic plurality. It, however, runs the risk of what Simmonds and Le Grange (2019) refer to as a 'quick-fix' in curriculum making.

The second approach is a decolonial approach. It is a resistance to the colonial matrix of power by making the invisible visible and changing both the terms and the content of knowledge-making. Nyoni (2019) postulates:

Decolonisation is a disruptive process of exposing and dismantling the obvious and hidden aspects of those institutions, linguistic and cultural forces that had maintained the imperialist power and that remain even after attainment of independence. (p. 7)

In changing both the terms and the content in curriculummaking, Nyoni (2019) proposes Afro-communitarian theory, which explains the person in relation, and the Afrohumanisation of pedagogy.

Simmonds and Le Grange (2019) engage curriculum through posthuman nomadic thought. Through nomadic thought and interventions, and not a 'quick-fix', transformative becoming is possible. They also advocate for a change in the terms and not only the content of conversations in and on curriculum-making. This may lead to engagement with the otherwise 'resources and traditions of thought that were never mainstreamed' (Simmonds \& Le Grange 2019:8).

\section{Alienation}

The \#mustfall protests unmasked brutal alienation through race, class and gender at South African universities (Bazana \& Mogotsi 2017; Becker 2017; Eybers 2019; Lamola 2018; Nyoni 2019; Rothmann 2018).

While Bazana and Mogotsi (2017) explore the relation between coloniality of knowledge and being in identity construction, Mabille (2019) unmasks the interrelated movement between coloniality of power, knowledge and being. During modernity, power was directed towards generating a self, a human, relating to himself through colonial knowledge. This colonial constructed hegemonic self still imposes on and demands from all others 'certain desirable characteristics by delegitimising all other alternatives as "other"' (Mabille 2019:3).

This is illustrated by Bazana and Mogotsi (2017) in their exploration of identity struggles of black students in South African universities. Euro-western knowledge, enunciating notions of being human, formed the basis for racial identities since colonialism. Apartheid formalised and legalised these binary identities. Bazana and Mogotsi (2017) argue that black identity has historically embodied inferiority, submissiveness and dependency. The inferior black and superior white discourses are still embedded in higher education through the logic of coloniality, and have detrimental effects on identity construction and belonging for black students in higher education.

Lamola (2018:2) focusses his exploration of coloniality of being and its relation to coloniality of knowledge on 'the complications and possibilities of lived black-experience-ina-white-racist-world'. He poses that:

Being a black person is not merely an idea of the Othering subject or a representation of a capricious colonial mind. It is a material reality of being, a facticity whose social ontology has to be selfnegotiated. (p. 7)

The ontological structuring happens when 'Others tell and teach her who she is, pricking and shaping her selfconsciousness. She is not her own' (Lamola 2018:7). Such experiences entail an ontological alienation from humanity through colonial epistemology.

Gender and sexuality are explored by Rothmann (2018), Tshilongo and Rothman (2019), Ramohai (2019) and Norris 
and Welch (2020). The effects of binary logic and heteronormativity on alienation in relation to sexuality and gender in higher education are evident in these publications. Norris and Welch (2020), in exploring gender-neutral pronouns through a posthuman lens, critique the influence of humanistic and colonial language on alienation for both humans and non-humans. They reference Fanon ([1961] 2017) in Wretched of the Earth in which he describes how the oppressed are animalised through language use. The consequences of this are binaries separating humans through sexualities, gender and race and the maintenance of the nature and culture binary.

In light of the digital interventions during the COVID-19 pandemic, in order to facilitate teaching and learning, there is a warning from Du Toit and Verhoef (2018) on the 'instrumentalist and disembodied understanding of (digital) technology and its potential impact on higher education'. Such approaches and understandings delimit embodiment and the entanglement between human and the artefact. It furthermore leads to a detached and alienating experience for the subjects of higher education. In combatting alienation and enabling human becoming through decoloniality, instrumentalist and disembodied understandings of technology, only deepen alienating practices in higher education.

\section{Concluding analysis}

In any analysis through a decolonial lens, there are three key units of analysis: coloniality of power, coloniality of knowledge and coloniality of being (Ndlovu-Gatsheni 2019). Coloniality of power as a unit of analysis is used to understand the global cartography of power. It is useful in exploring how global political and economic structures were constructed and constituted, and how they are maintained as hierarchies holding the 'Euro-American-centric, Christian-centric, patriarchal, capitalist, hetero-normative, hegemonic and asymmetrical' systems and structures in place (NdlovuGatsheni 2019:216). Coloniality of knowledge as a unit of analysis unpacks epistemological issues, the politics of knowledge, who constructs knowledge and for what purpose is knowledge constructed and disseminated (Ndlovu-Gatsheni 2019). Epistemology is a key concept in analysing coloniality as it is inherent to both levels of the colonial matrix of power. Coloniality of being concerns the key issues of human subjectivity and human ontology (Ndlovu-Gatsheni 2019). The three units are separated for analytical purposes but are interrelated through continual upward and downward movements. The analysis does not focus on the three units separately but the interrelated movements between them.

The published authors engage with power, knowledge and being. The powerful and embedded role of knowledge (European, Euro-western, securitised, globalised, African, colonial, intercultural, transcultural, internationalised) and knowledge-making is clear. Local and international authors navigate these contestations sufficiently. There is also a variety of perspectives on the role of place - both local and global.
In light of the privileged role of knowledge in the colonial matrix of power, some comments on epistemology and epistemological practices are needed. Although authors clearly want to bridge different and competing hegemonic knowledge systems through notions of intercultural, transcultural and cross-border conversations and knowledge, the notion of bridging binary knowledge hegemonies remains a false premise for transformation. In decolonial thinking (and in posthumanism), there are no borders, universals, binary or competing hegemonies. There are multiple embedded, embodied, lived, local and global knowledge and epistemologies. Mignolo (2018b) argues that pluriversality is the universal. The notion that the bridging of Eurocentric and African knowledge systems is possible by adding indigenous knowledge to a Eurocentric curriculum is a false notion. This notion has detrimental consequences for transformation in higher education in South Africa. This is described in various publications in this journal (Heleta 2016; Matolino 2020; Nyoni 2019).

Enacting global pluriversality relies on changing the terms of conversations on curriculum-making and knowledge. Simmonds and Le Grange (2019) touch on that when they discuss the possibilities of nomadic thought and interventions for curricula. There need to be changes to the rules, terms and assumptions in knowledge-making. Decolonial knowledgemaking happens in 'a web of consensual relationships that is infused with movement through lived experiences and embodiment' (Walsh 2018:18). Pluriversality includes Eurowestern knowledge. It de-centres Euro-western knowledge towards a pluriversalisation of multiple knowledge. Higher education needs an embedded and embodied pluriversalisation in order to think differently.

There are numerous possibilities presented for changing the content (enunciated) in conversations on transformation, not only in this journal but in the academe as well. This mostly consists of add-ons to existing curricula (see e.g. Eybers 2019 on epistemic plurality). Very little research is done and published on changing the terms (enunciation) of conversations on transformation. What is the enunciation of transformation in higher education, who enunciates and from where? If the enunciation of transformation happens through a Euro-western point of reference, the terms of conversation cannot change. The terms of conversations on transformation are changed through decolonial resistance and analysis. There is a dire need to unmask, unpack and make visible the terms by which knowledge is made, for who, and by who, in higher education. Ndlovu-Gatsheni (2019:215) postulates that it is the 'core task' of decoloniality to analyse, unmask, make visible and problematise enunciation in the colonial matrix of power. Only then can the content (enunciated) be decolonised.

Pluriversalisation might lead to the liberation of a pluriversal humanity, to embedded and embodied pluriversal identities and embedded and embodied pluriversal subjectivities. Pluriversal knowledge enacts and validates pluriversal ways 
of being and living. The colonial alienation of being, still evident in higher education, as described by Bazana and Mogotsi (2017), Lamola (2018) and Mabille (2019), remains devastating. It needs serious attention in education research and transformation research.

Resisting the colonial matrix of power and changing the terms of conversations on transformation is furthermore always a bottom-up process. It is premised on deep engagements with grassroots struggles and movements. Although the \#mustfall protests are explored by various authors (Becker 2017; Davids 2016; Matolino 2020), there is a lack of publications on grassroots and bottom-up research. A lack of community engagement in research was already highlighted by Du Preez et al. (2016), when they did a metaanalysis of articles on transformation published in South African Journal of Higher Education in South Africa from 2005 to 2015. This seems to be an ongoing trend.

Kumalo and Praeg (2019) argue that given the complex and sometimes elusive and contested meaning of the concept of decoloniality, it often morphs into a performance - a decolonial performance which is ticked off from the list of transformation tasks. They argue that there is a lack of substantive and fundamental engagement with decolonial discourses and praxis in South African transformation conversations (Kumalo \& Praeg 2019). Although I find the engagement with transformation from most authors writing on decoloniality substantive, I agree that there is a lack of engagement with specifically decoloniality and decolonial analysis. There has, however, been growth in the depth of published articles on transformation and decoloniality since 2016 in the journal.

In conclusion, what I found interesting in reading through the articles published in this journal was the multiple uses of the word beyond. There is a quest by authors for movement away from what higher education is now.

Davids (2016:1) argues for the need to move 'beyond the thus far truncated parameters of transformation'. Bazana and Mogotsi (2017:10) pose that 'universities need to go beyond the legislative prescripts of inclusivity'. Smith and Vass (2017:1) argue that students should be encouraged 'to go beyond instrumental approaches to learning'. Whilst Davids (2016), Bazana and Mogotsi (2017) and Smith and Vass (2018) use the word beyond as a preposition (going to the further side of, or past this or that), Lamola (2018) uses it as the beyondthe unknown or the outside. He laments:

When we later add references to the psycho-social experiences of black students in white-majority or white-dominated educational institutions, this article will explicatively argue that the task before the academy is more than pedagogic and may be beyond the theme of 'transforming higher education' (Lamola 2018:2, own emphasis)

He argues that there are things that are in the beyond of transformation. Mabille (2019:1) argues towards a 'reconsidered and reconfigured notion of educational identity beyond the confines of modernist Western subjectivity'. The use of the word beyond here is in reference to Foucault's notion 'of the unthought' (Mabille 2019:6). There are thus suggestions that transformation in higher education should move to the unknown, to the unthought and to the outside of certainty.

Walsh (2018) similarly speaks of a decolonial beyond - a decolonial otherwise. The consequences of the COVID-19 pandemic illuminated the lasting consequences of the logic of coloniality and reiterated the need for a global decolonial otherwise. In times of uncertainty, constant change and disruption, the beyond might be the only option. Reimaginations, beyond transformation, may then become pandemic.

\section{Acknowledgements Competing interests}

The author has declared that no competing interests exist.

\section{Authors' contributions}

The author declares that she is the sole author for this research article.

\section{Ethical consideration}

This article followed all ethical standards for research without direct contact with human or animal subjects.

\section{Data availability statement}

Data sharing is not applicable to this article as no new data were created or analysed in this study.

\section{Disclaimer}

The views and opinions expressed in this article are those of the author and do not necessarily reflect the official policy or position of any affiliated agency of the author.

\section{References}

Bazana, S. \& Mogotsi, O.P., 2017, 'Social identities and racial integration in historically white universities: A literature review of the experiences of black students', Transformation in Higher Education 2(0), a25. https://doi. org/10.4102/the.v2i0.25

Becker, A., 2017, 'Rage, loss and other footpaths: Subjectification, decolonisation and transformation in higher education', Transformation in Higher Education 2(0), a23. https://doi.org/10.4102/the.v2i0.23

Davids, N., 2016, 'On extending the truncated parameters of transformation in higher education in South Africa into a language of democratic engagement and justice', Transformation in Higher Education 1(1), a7. https://doi.org/10.4102/the.v1i1.7

Du Preez, P., Simmonds, S. \& Verhoef, A.H., 2016, 'Rethinking and researching transformation in higher education: A meta-study of South African trends', Transformation in Higher Education 1(1), a2. https://doi.org/10.4102/the.v1i1.2

Du Toit, J. \& Verhoef, A.H., 2018, 'Embodied digital technology and transformation in higher education', Transformation in Higher Education 3(0), a52. https://doi. org/10.4102/the.v3i0.52

Eybers, O.O., 2019, 'Applying Ayittey's Indigenous African Institutions to generate epistemic plurality in the curriculum', Transformation in Higher Education $4(0)$, a68. https://doi.org/10.4102/the.v4i0.68

Fanon, F. [1961] 2017, The wretched of the earth, Kwela Books, Cape Town.

García, R. \& Baca, D., 2019, 'Introduction. Hopes and visions: The possibility of decolonial options', in R. García \& D. Baca (eds.), Rhetoric elsewhere and otherwise. Contested modernities. Decolonial visions, pp. 1-46, NCTE, Illinois USA. 
Gearon, L.F., 2017, 'The counter-terrorist campus: Securitisation theory and university securitisation - Three Models', Transformation in Higher Education 2(0), a13. securitisation - Three Models', Trans
https://doi.org/10.4102/the.v2io.13

Gearon, L.F., 2019, 'Securitisation theory and the securitised university: Europe and the nascent colonisation of global intellectual capital', Transformation in Higher Education 4(0), a70. https://doi.org/10.4102/the.v4i0.70

Heleta, S., 2016, 'Decolonisation of higher education: Dismantling epistemic violence and Eurocentrism in South Africa', Transformation in Higher Education 1(1), a9. https://doi.org/10.4102/the.v1i1.9

Horsthemke, K., 2017, 'Transmission and transformation in higher education: Indigenisation, internationalisation and transculturality', Transformation in Higher Education 2(0), a12. https://doi.org/10.4102/the.v2i0.12

Kumalo, S.H. \& Praeg, L., 2019, 'Editorial. Decoloniality and justice a priori', Journal of Decolonising Disciplines 1(1), 1-9.

Lai, I.C.C., 2018, 'Global world, global mind: Narratives of the University of Hong Kong Worldwide Exchange students', Transformation in Higher Education 3(0), a42. https://doi.org/10.4102/the.v3i0.42

Lamola, M.J., 2018, 'Blackhood as a category in contemporary discourses on Black Studies: An existentialist philosophical defence', Transformation in Higher Education 3(0), a55. https://doi.org/10.4102/the.v3i0.55

Mabille, M.L., 2019, 'Foucault and the origins of the disciplined subject: Postsubjectivity as a condition for transformation in education', Transformation in Higher Education 4(0), a72. https://doi.org/10.4102/the.v4i0.72

Maldonado-Torres, N., 2007, 'On the coloniality of being', Cultural Studies 21(2-3), 240-270.

Maldonado-Torres, N., 2016, 'Outline of ten theses on coloniality and decoloniality', Franz Foundation, viewed 2 October 2020, from http://franzfanonfoundation.

Mariaye, H. \& Samuel, M., 2018, 'Education hubs and private higher education expansion in small island developing states contexts: The case of Mauritius', Transformation in Higher Education 4(0), a62. https://doi.org/10.4102/the.v4i0.62

Matolino, B., 2020, 'Philosophers' debt to their students: The South African case', Transformation in Higher Education 5, a87. https://doi.org/10.4102/the.v5i0.87

Mbembe, A., 2020, 'The universal rights to breathe', Critical Inquiry, viewed 5 October 2020, from https://critinq.wordpress.com/2020/04/13/the-universalright-to-breathe/.

Mignolo, W.D., 2018a, 'The conceptual Triad: Modernity/coloniality/decolonial', in W.D. Mignolo \& C.E. Walsh (eds.), On decoloniality, pp. 135-152, Duke University Press, Durham, NC.

Mignolo, W.D., 2018b, 'What does it mean to decolonise?' in W.D. Mignolo \& C.E. Walsh (eds.), On decoloniality, pp. 105-134, Duke University Press, Durham, NC.

Ndlovu-Gatsheni, S.J., 2015, 'Decoloniality as the future of Africa', History Compass 13(10), 485-496.

Ndlovu-Gatsheni, S.J., 2019, 'Discourses of decolonisation/decoloniality', Papers on Language and Literature 55(3), 201-226.

Nell, I.A., 2020, 'Competency-based theological education in a postcolonial context: Towards a transformed competency framework' Transformation in Higher Education 5(0), a74. https://doi.org/10.4102/the.v5i0.74
Norris, M. \& Welch, A., 2020, 'Gender pronoun use in the university classroom: A post-humanist perspective', Transformation in Higher Education 5(0), a79. https:// post-humanist perspective',
doi.org/10.4102/the.v5i0.79

Nyoni, J., 2019, 'Decolonising the higher education curriculum: An analysis of African intellectual readiness to break the chains of a colonial caged mentality', Transformation in Higher Education 4(0), a69. https://doi.org/10.4102/the.v4i0.69

Peters, M.A., Rizvi, F., McCulloch, G., Gibbs, P., Gorur, R., Hong, M. et al., 2020, 'Reimagining the new pedagogical possibilities for universities post-Covid-19', Educational Philosophy and Theory. https://doi.org/10.1080/00131857.2020.177 7655

Ramohai, J., 2019, 'A black woman's perspective on understanding transformation and diversity in South African higher education', Transformation in Higher Education 4(0), a58. https://doi.org/10.4102/the.v4i0.58

Ramrathan, L., 2016, 'Beyond counting the numbers: Shifting higher education transformation into curriculum spaces', Transformation in Higher Education 1(1), a6. https://doi.org/10.4102/the.v1i1.6

Rothmann, J., 2018, 'A social constructionist approach to resilience for lesbian, gay, bisexual, transgender, intersex, queer and/or questioning academics and students in South African universities', Transformation in Higher Education 3(0), a34. https://doi.org/10.4102/the.v3i0.34

Simmonds, S. \& Le Grange, L., 2019, 'Research in curriculum studies: Reflections on nomadic thought for advancing the field', Transformation in Higher Education 4(0), a76. https://doi.org/10.4102/the.v4i0.76

Smith, M.K. \& Vass, V., 2017, 'The relationship between internationalisation, creativity and transformation: A case study of higher education in Hungary', Transformation in Higher Education 2(0), a22. https://doi.org/10.4102/the.v2i0.22

Suárez-Krabbe, J., 2013, 'Democratising democracy, humanising human rights. European decolonial movements and the "Alternative Thinking of Alternatives", Migration Letters 10(3), 333-341. https://doi.org/10.33182/ml.v10i3.132

Tshilongo, T. \& Rothmann, J., 2019, 'A sociological exploration of the need for safe spaces for lesbian and gay students on a South African university campus', Transformation in Higher Education 4(0), a77. https://doi.org/10.4102/the.v4i0.77

Van de Laar, M., Rehm, M. \& Achrekar, S., 2017 "'Community of Learning" for African PhD students: Changing the scene of doctoral education?', Transformation in Higher Education 2(0), a17. https://doi.org/10.4102/the.v2i0.17

Venter, R., 2016, 'Theology and the (post-)apartheid university: Mapping discourses, interrogating transformation', Transformation in Higher Education 1(1), a5. https://doi.org/10.4102/the.v1i1.5

Walsh, C.E., 2018, 'The decolonial for: Resurgences, shifts and movements', in W.D. Mignolo \& C.E. Walsh (eds.), On decoloniality, pp. 15-32, Duke University Press, Durham, NC.

Waghid, Y., 2016, 'Transformation as an act of denudation: A response to Petro du Preez, Shan Simmonds and Anné Verhoef', Transformation in Higher Education 1(1), a3. https://doi.org/10.4102/the.v1i1.3

Zembylas, M., 2018, 'The entanglement of decolonial and posthuman perspectives: Tensions and implications for curriculum and pedagogy in higher education', Parallax 24(3), 254-267. https://doi.org/10.1080/13534645.2018.1496577 